\title{
The Effect of Business Strategy on Manipulation of Real Activities
}

\author{
Eva Herianti $^{*}$, Amor Marundha ${ }^{2}$ \\ ${ }^{1}$ Faculty of Economic and Business, Muhammadiyah University \\ Email: heriantieva@gmail.com \\ ${ }^{2}$ Faculty of Economic and Business, Persada YAI University
}

\begin{abstract}
This study aimed to examine the effect of low cost strategy and differentiation strategy on the manipulation of real activity. Sample selection was done by using purposive sampling at manufacturing companies listed in Indonesia Stock Exchange (BEI) in the period of 20122016 with analysis period 2014-2016 and get final sample that consist of 358 observations. The research findings show that the low-cost strategy did not significantly affect the manipulation of real activity, while the differentiation strategy negatively and significantly affected the manipulation of real activity.
\end{abstract}

Keywords: Low Cost Strategy, Differentiation, Manifest Activity

\section{Introduction}

The financialstatements arethesourceofinformation usedbystakeholders indecisionmaking. Such information is reflected through the earnings information reported by the company's management onthe income statement. Dechow and Dichev (2002) explained that qualified earnings information must meet three important characteristics: (1) able to explain the operational performance of the company appropriately, (2) able to be a good indicator in assessing the company's performance in the future, and (3) can be an accurate benchmark in assessing company'sperformance.

Graham et al. (2005), Roychowdhury (2006) and Cohen et al. (2008) stated that company management tends to like real activity manipulation activity when compared to accrual-based earnings manipulations. This research is important to provide evidence that the earnings information contained in the financial statements contain quality information because of the right business decisions made by the management company. The objective of this study was to examine and analyze the effect of low cost strategy and differentiation on the manipulation of real activity.

\section{Theoretical Review and Development of Hypotheses}

\subsection{Theoretical Review}

\subsubsection{Agency Theory}

Jensen and Meckling (1976) explained that shareholders provide a mandate to the company's management to manage the company's activities. Such actions are reflected through a business strategy that will benefit shareholders. 


\subsubsection{Pecking Order Theory}

Pecking Order theory states that companies prefer to use internal funding rather than external funding, secure debt versus risky debt and common stock (Myers and Majluf, 1984). The greater the company's management decision to divide the dividend to shareholders, the smaller the company's remaining profits.

\subsubsection{Business Strategy}

The business strategy typology proposed by Porter (1980) focuses on three business strategies: low cost, differentiation and focus. Low cost strategy refers to the efficiency of production. Differentiation strategy refers to product differentiation and high degree of relationship between customers and companies. The focus strategy refers to the implementation of a low-cost strategy within a purchasing or market group.

This research focuses more on the two main strategies of low cost strategy and differentiation strategy because these two strategies tend to be used by companies (David et al., 2002; Kald, 2003; Chen, 2006; Banker et al., 2011).

\subsubsection{Manipulation of Real Activities}

Profit manipulation is an intervention of company management that is done to obtain certain benefits (Schiper, 1989). Studies related to earnings manipulation have shown that company management has shifted from the manipulation of accrual-based earnings to manipulation of real activity. Studies conducted by Gunny (2005), Roychowdhury (2006) and Cohen and Zarowin (2008) suggest that company management has shifted from the manipulation of accrual-based earnings to manipulation of real activity after the Sarbanes- Oxley Act (SOX) period.

\subsection{Hypothesis Development}

\subsubsection{Low Cost Strategy and Real Activity Manipulation}

One of the factors causing the company's management action to manipulate the profit is the need of the company in obtaining financing from external parties either through equity shares or debt. The research conducted by Wu et al. (2015) show that the low-cost strategy has a positive effect on the manipulation of real activity. Based on the description, the hypothesis proposed in this study is:

H1: Low cost strategy has a positive effect on the manipulation of real activity.

\subsubsection{Differentiation Strategies and Manipulation of Real Activities}

The differentiation strategy adopted by company management shows that with the uniqueness of the product being offered, the company will get a higher price. The results of research conducted by $\mathrm{Wu}$ et al. (2015) suggest that differentiation strategies negatively affect the manipulation of real activity. The hypothesis proposed in this study is:

H2: Differentiation strategies negatively affect the manipulation of real activity. 
Table 1. Process of Sample Selection

\begin{tabular}{lll}
\hline No. & Sample Criteria & Total Sample \\
\hline 1. & Manufacture company listed in BEI 2012-2016 & 131 \\
\hline 2. & Incomplete data & $(9)$ \\
\hline & Research sample & 122 \\
\hline & Observation sample of this research (122 X 3 years) & 366 \\
\hline Outlier & $(8)$ \\
\hline & Final Observation Sample & 358 \\
\hline Source: & www.idx.co.id
\end{tabular}

\section{Research Method}

\subsection{Data and Sample Selection}

Manufacturing companies are selected in this study as samples because manufacturing firms are more complex than other companies that have different strategies for dealing with tough competition.

\subsection{Operational Definition}

This study involves the independent and dependent variables used to test the proposed hypothesis. The independent variables in this research are business strategy covering low cost strategy and differentiation strategy. The dependent variable in this research is manipulation of real activity.

\subsubsection{Manipulation of Real Activities}

Manipulation of real activities is the profits management made by company management through real activity during the accounting period. Roychowdhury (2006) classifies the manipulation of real activity through operating cash flows, production costs, and discretionary costs.

1. Manipulation of Real Activity through Cash Flow of Operating Activities

According to Roychowdhury (2006), to detect the manipulation of real activity through operating cash flows, it is necessary to estimate the cash flow for normal operating activities of firms with regression equations as follows:

$$
\mathrm{CFOt} / \mathrm{At}-1=\alpha 0+\alpha 1(1 / \text { At- } 1)+\beta 1(\mathrm{St} / \mathrm{At}-1)+\beta 2(\Delta \mathrm{St} / \mathrm{At}-1)+\mathrm{\epsilon t}
$$

Information:

CFOt / At-1 : Operating current in year $t$ which is scaled by total assets in year $t-1$.

A1 (1/At-1) : The scaled intercept with total assets in year $\mathrm{t}-1$ with the objective of operating operation not having a value of 0 when sales and sales lags value 0 .

St / At-1 : sales in year $\mathrm{t}$ which is scaled by total assets in year $\mathrm{t}-1$.

$\Delta \mathrm{St} / \mathrm{At}-1 \quad$ : sales in year $\mathrm{t}$ minus sales in year $\mathrm{t}-1$ which is scaled by total assets in year $\mathrm{t}-1$.

A0 : Constants.

$\mathrm{Et} \quad$ : Errorterm in year $\mathrm{t}$. 
After obtaining the estimated coefficient, then the cash flow calculated abnormal operation for each year observation with the following equation.

$$
\mathrm{ACFO}=\mathrm{CFOt}-\mathrm{CFOt} / \mathrm{At}-1
$$

\section{Manipulation of Real Activities through Production Costs}

The production cost in this study is obtained from the sum of cost of goods sold (COGS) and changes in inventory $(\Delta \mathrm{INV})$. Roychowdhury (2006) uses estimation model to calculate the normal production cost as follows:

$$
\begin{aligned}
& \text { PRODt } / \text { At- } 1=\alpha 0+\alpha 1(1 / \text { At- } 1)+\beta 1(\text { St } / \text { At- } 1)+ \\
& \beta 2(\Delta \text { St } / \text { At- } 1)+\beta 3(\Delta \text { St- } 1 / \text { At- }-1)+\epsilon t
\end{aligned}
$$

Information:

PRODt /At-1 : Production cost in year $\mathrm{t}$ which is scaled by total assets in year $\mathrm{t}-1$, where PRODt $=$ COGSt $+\Delta \mathrm{INVt}$

A (1/At-1) : The scaled intercept with total assets in year $t-1$ for the production cost value to be 0 when the sale and the sales lag are 0 .

St / At-1 : Sales in year $t$ which is scaled by total assets in year $t-1$.

$\Delta \mathrm{St} / \mathrm{At}-1 \quad$ : Sales in year $\mathrm{t}$ minus sales in year $\mathrm{t}-1$ which is scaled by total assets in year $\mathrm{t}-1$.

$\Delta$ St-1 / At-1 : Changes in sales in the year $\mathrm{t}-1$ is scaled by total assets in year $\mathrm{t}-1$.
A0
: Constants
Et
: Error term at year $\mathrm{t}$.

After obtaining the estimated coefficient, then the abnormal production cost calculated for each observation year with the following equation.

$$
\text { APROD }=\text { PRODt }- \text { PRODt } / \text { At-1 }
$$

\section{Manipulation of Real Activities through Discretionary Costs}

Discretionary costs in this study were obtained by summing up advertising costs, research and development costs, sales and administrative and general costs. The regression model used to calculate the normal discretionary costs following Roychowdhury (2006) study is as follows:

$$
\text { DISt } / \text { At- } 1=\alpha 0+\alpha 1(1 / \text { At- } 1)+\beta(\text { St- } 1 / \text { At- } 1)+\epsilon t
$$

Information:

DISt / At-1 : Discretionary costs in year $t$ which is scaled with total assets of year $t-1$

A (1/At-1) : The scaled-up intercept with total assets in year t-1 with the aim that the cricketexis does not have a value of 0 in sales and the sales lag is 0 .

St-1 / At-1 : Sales in year t-1 is scaled with total assets in year t-1.

A0 : Constants

Et : Error term at year $\mathrm{t}$. 
After obtaining the estimated coefficient, we calculated the abnormal discretionary cost (ABN_DIS) for each year observation with the following equation.

$$
\text { ADIS }=\text { DISt }- \text { DISt } / \text { At-1 }
$$

To obtain a comprehensive real-life manipulation measure, the above three components are accumulated, namely abnormal production cost (APROD), abnormal cash flow operation (ACFO), and abnormal discretionary expenses (ADIS). Research conducted by Zang (2012) and Cohen et al. (2008) found that, to obtain a comprehensive proxy of the manipulation of real activity, then first align the direction of abnormal cash flow operation and abnormal expense by multiply it with -1 , then summed all three proxies above to obtain the overall proxies of manipulation of real activity. Thus, the above formula can be written as follows.

$$
\text { MALR }=\text { ACFO (-1) }+ \text { ADIS (-1) }+ \text { APROD }
$$

The above formula can be simplified according to the combination result used by Wu et al. (2015) based on Zang (2012) and Cohen et al. (2008), as follows:

$$
\text { MALR }=\text { APROD }- \text { ACFO }- \text { ADIS }
$$

\subsubsection{Business Strategy}

This study utilized the business strategy from Porter (1985) which consists of low cost strategy (low cost) and differentiation strategy (differentiation). Low cost strategy is measured by asset utilization efficiency which shows how important operational efficiency for company. The formula for calculation of low cost strategy adopted from research Gani and Jermias (2006) as follows:

Asset Utilization Efficiency $=$ Sales $/$ Assets

Differentiation strategy shows the company's ability in using premium price. Differentiation strategy formula adopted from research Wu et al. (2015) as follows:

$$
\text { Profit Margin }=\frac{\text { Operational profit }=R \& D \text { Cost }}{\text { Sales }}
$$

Hypothesis testing used is multiple linear regression model multiple linear regression is used to test (1) the influence of tax planning and political connection to manipulation of real activity. The mathematical equations for hypothesis testing in research are as follows:

$$
\mathrm{YMLR}=\alpha+\beta 1 \mathrm{SBR}+\beta 2 \mathrm{SDI}+\mathrm{e}
$$

Information:

MLR : Manipulation of Real Activities

SBR : Low Cost Strategy (Low Cost)

SDI : Differentiation Strategy 
Table 2. Descriptive Statistics

\begin{tabular}{llll}
\hline Variable & $\mathbf{N}$ & Mean & Std. Deviasi \\
\hline MLR & 358 & 0.20 & 7.027 \\
\hline SBR & 358 & 1.11 & 0.846 \\
\hline SDI & 358 & -0.09 & 6.861 \\
\hline
\end{tabular}

Source: Processed secondary data, 2017

\section{Analysis and Discussion}

\subsection{Analysis}

Descriptive statistics used in this study aims to provide a brief overview of research variables. Table 2 shows the description of the variables used in this study. Table 2 shows that the average manipulation of real activity conducted by manufacturing companies sampled in this study is positive value is 0.20 . This reflects that the behavior manipulation real activity by company's management is to increase the profit. In addition, the standard deviation of this variable is 7.027 which shows the volatility of earnings manipulation behavior undertaken by the firm's management.

Variable low cost business strategy (low cost) shows the average value of positive value that is 1.11 which means that the existence of corporate management behavior in making production efficiency as a competitive strategy. In addition, the standard deviation of this variable shows volatility with a value of 0.846 .

Differentiation strategy variables have a negative average value of -0.09 reflects a decrease in corporate management behavior in using this strategy. In addition, the standard deviation of this variable indicates volatility with a value of 6,861 .

\subsubsection{Classical Assumption Testing Results}

The classical assumption test used in this study to obtain an accurate testing strength (BLUE).

The classical assumption test results are as follows.

1. Normality Test

Table 3 shows that the results of normality testing using Kolmogorov smirnov have met the assumption of normality. This is indicated by the significance value of the calculation is $0.068>$ 0.05. Thus, the variable used in this study residual has been normal distributed.

2. Multicollinearity test

Table 4 shows that multicollinearity test results using tolerance and VIF values have met the multicollinearity assumptions. This is shown by the value of tolerance $>0.1$ and the VIF value $<10$. Thus, the variable used in the study is free from symptoms of multicollinearity. 
Table 3. Normality Test Result

\begin{tabular}{ll}
\hline & Normality Test \\
\hline Significant & 0.068 \\
\hline Source: processed secondary data, 2017 &
\end{tabular}

Table 4. Multicolinearity Test Result

\begin{tabular}{lll}
\hline Variable & \multicolumn{2}{l}{ Collinearity Statistics } \\
\cline { 2 - 3 } & Tollerance & VIF \\
\hline SBR & 0.997 & 1.003 \\
\hline SDI & 0.997 & 1.003 \\
\hline Source: processed secondary data, 2017 & &
\end{tabular}

Table 5. Heteroskedastisity Test Result

\begin{tabular}{lll}
\hline Variable & Testing Result & \\
\cline { 2 - 3 } & t-Count & Sig. \\
\hline SBR & -0.629 & 0.530 \\
\hline SDI & 0.142 & 0.888 \\
\hline Source: processed secondary data, 2017 & &
\end{tabular}

Table 6. Autocorrelation Test Results

\begin{tabular}{ll}
\hline & Nilai \\
\hline Durbin-Watson & 1.979 \\
\hline Source: processed secondary data, 2017 &
\end{tabular}

\section{Heteroscedasticity Test}

Table 5 shows that the results of heteroscedasticity testing using the glejser test have met the heteroscedasticity assumption. This is indicated by the significance value of the calculation result more than 0.05 . Thus, the variables used in this study are free of symptoms of heteroscedasticity.

4. Autocorrelation Test

Table 6 shows that the results of autocorrelation testing using durbin-watson have met the autocorrelation assumption. This is indicated by the $\mathrm{D}-\mathrm{W}$ value of the calculation is in the range -2 to 2 . Thus, the variable used in this study is free from autocorrelation symptoms.

\subsection{Discussion}

Table 7 demonstrates the hypothesis testing results to explain the effect of low-cost business strategy and differentiation on the manipulation of real activity. Based on the data on Table 7, low-cost business strategy variables and differentiation strategies can account for real-life manipulation variables of $21.6 \%$. While $78.4 \%$ is explained by other variables that are not involved in this study. 
Table 7. Hypothesis Test Results

\begin{tabular}{lllll}
\hline Variable & Expectation & Coefficient & T & Sig. \\
\hline (Constant) & & 0.012 & 0.022 & 0.982 \\
\hline SBR & + & 0.132 & 0.338 & 0.736 \\
\hline SDI & - & -0.476 & -9.880 & 0.000 \\
\hline Dependent: MLR & & & \\
R2 $\quad=0.216$ & & & \\
F $=48.824$ & & & \\
Sig. $\quad=0.000$ & & &
\end{tabular}

\subsubsection{Low Cost Business Strategy and Manipulation of Real Activities}

Hypothesis 1 reads a low-cost strategy has a positive effect on the manipulation of real activity. Test results in Table 7 shows that the low-cost strategy has a coefficient of $0.132, t$ arithmetic of 0.338 , and a significance value of 0.736 (more than 0.05 ). Based on the test results, the lowcost strategy does not significantly influence the manipulation of real activit $y$. The results of this study are not consistent with the results of research conducted by Wu et al. (2015) indicating that low-cost strategies have a positive effect on the manipulation of real activity.

\subsubsection{Business Strategy Differentiation and Manipulation of Real Activities}

Hypothesis 2 reads a differentiation strategy negatively affecting the manipulation of real activity. Test results in Table 7 shows that the differentiation strategy has coefficient of $-0.476, \mathrm{t}$ arithmetic of -9.880 , and a significance value of 0.000 (less than 0.05 ). Based on the test results, the differentiation strategy has a negative and significant effect on the manipulation of real activity.

\section{Conclusions and Suggestions}

\subsection{Conclusions}

This study aimed to test and analyze the influence of business strategy both low-cost strategy and strategy against manipulation of real activity. The sample of this study is a manufacturing company listed on the Indonesia Stock Exchange (IDX) period 2012-2016.

Business strategy of a company can be done through a low-cost strategy (low cost) and differentiation strategy (differentiation). The low-cost strategy is done by using existing resources efficiently to obtain optimal results. The differentiation strategy has the purpose of obtaining a higher price because the company sells more products at a certain price.

\subsection{Limitations}

This study has several limitations that need to be the attention of further research such as:

i. The use of proxies that explain the variables of low-cost business strategy that is asset utilization efficiency and differentiation strategy that is profitmargin.

ii. Testing the factors that influence the behavior of manipulation of real activity is limited to business strategy without looking at other factors. 


\subsection{Suggestions}

The suggestions for further researchers are as follows.

i. Further researches are expected to use other proxies that explain the business strategy be it low-cost and differentiated strategies to obtain more comprehensive results.

ii. Further researches can use other factors that influencethe behavior of manipulation of real activity.

\section{References}

Banker, R.D., Hu, N., Pavlou, P.A. and Luftman, J. (2011), "CIO reporting structure, strategic positioning, and firm performance”, MIS Quarterly, Vol. 35 No. 2, pp. 487-504.

Bart, M., J. Elliott, and M. Finn. 1999. Market rewards associated with patterns of increasing earnings. Journal of Accounting Research 37 (2): 387-413.

Barto, E., D. Givoly, and C. Hayn. 2002. The rewards to meeting or beating earnings expectations. Journal of Accounting and Economics 33: 173-204.

Bernard, V., J. Thomas, and J. Abarbanell. 1993. How sophisticated is the market in interpreting earnings news? Journal of Applied Corporate Finance 6 (2): 5463.

Brown, L., and M. Caylor. 2005. A temporal analysis of quarterly earnings thresholds: Propensities and valuation consequences. The Accounting Review 80 (2): 423.440.

Bushman, R. M., and A. J. Smith. 2001. Financial Accounting Information and Corporate Governance. Journal of Accounting and Economics. Vol. 32:237-333.

Chen, S. (2006), "Market orientation and guanxi in Chinese business enterprises - substitutes or complements?", unpublished doctoral dissertation, University of New South Wales, Sydney.

Cohen, D. A., A. Dey, and T. Z. Lys. 2008. Real and Accrual-Based Earnings Management inthe Pre- and Post-Sarbanes-Oxley Periods. The Accounting Review. Vol. 83, No. 3:757-787.

Cohen, D. A., and P. Zarowin. 2008. Economic Consequences of Real and Accrual-Based Earnings Management Activities. Working Paper. SternSchool of Business New York University.

David, J.S., Hwang, Y., Pei, B.K.W. and Reneau, J.H. (2002), "Source: the performance effects of congruence between product competitive strategies and purchasing management design”, Management Science, Vol. 48 No. 7, pp. 866-885. 
Dechow, P.M. and Sloan, R.G. (1991), "Executive incentives and the horizon problem: an empirical investigation", Journal of Accounting and Economic, Vol. 14 No. 1, pp. 145-176.

Dechow, P. M., and I. D. Dichev. 2002. The Quality of Accruals and Earnings:The Role of Accrual Estimation Errors. The Accounting Review. Vol. 77. Supplement: 35-59.

Eisenberg, T., Sundgren, S. and Wells, M.T. (1998), "Larger board size and decreasing firm value in small firms", Journal of Financial Economics, Vol. 48 No. 1, pp. 35-54.

Frankel, R., McNichols, M. and Wilson, G.P. (1995), "Discretionary disclosure and external financing", Accounting Review, Vol. 70 No. 1, pp. 135-150.

Gani, L., and J. Jermias. 2006. Investigating the effect of board independence on performanceacross different strategies. The International Journal of Accounting, 41, 295-314.

Govindarajan, V. and Gupta, A.K. (1985), "Linking control systems to business unit strategy: impact on performance", Accounting, Organizations and Society, Vol. 10 No. 1, pp. 51-66.

Govindarajan, V. and Fisher, J. (1990), "Strategy, control systems, and resource sharing: effects on business-unit performance", Academy of Management Journal, Vol. 33 No. 2, pp. 259-285.

Graham, J. R., C. R. Harvey, and S. Rajgopal. 2005. The Economic Implications Of Corporate Financial Reporting. Journal of Accounting and Economics.Vol. 40. No. 1: $3-73$.

Gujarati, Damodar. 2003. Ekonometrika Dasar : Edisi Keenam. Jakarta: Erlangga.

Gunny, K. 2005. What Are the Consequences of Real Earnings Management? Working Paper.

Ittner, C.D., Larcker, D.F. and Rajan, M.V. (1997), "The choice of performance measures in annual bonus contracts", The Accounting Review, Vol. 72 No. 2, pp. 231-255.

Jaggi, B.L. (1975), "The impact of the cultural environment on financial disclosures", International Journal of Accounting, Vol. 10 No. 2, pp. 75-84.

Jensen, M.C. (1993), "The modern industrial revolution, exit, and the failure of internal controlsystems", The Journal of Finance, Vol. 48 No. 3, pp. 831-880.

Jensen, M. C., and W. Meckling. 1976. Theory of the Firm: Managerial Behavior, Agency Costs and Ownership Structure. Journal of Financial Economics. Vol. 3: 305-360.

Jones, J. (1991), "Earnings management during import relief investigations", Journal of Accounting Research, Vol. 29 No. 2, pp. 193-228

Kald, M. (2003), "Strategic positioning: a study of the Nordic paper and pulp industry", Strategic Change, Vol. 12 No. 6, pp. 329-343. 
Kasznik, R., and M. McNichols. 2002. Does meeting earnings expectations matter? Evidencefromanalyst forecast revisions and share prices. Journal of Accounting Research 40 (3): 727-759.

Kim, E., Nam, D. and Stimpert, J.L. (2004), “Testing the applicability of Porter's generic strategies in the digital age: a study of Korean cyber malls", Journal of Business Strategies, Vol. 21 No. 1, pp. 19-45.

Miles, R.E. and Snow, C.C. (1978), Organizational Strategy, Structure and Process, McGraw- Hill, New York, NY.

Miles, R.E. and Snow, C.C. (2003), Organizational Strategy, Structure, and Process, StanfordUniversity Press, Stanford, CA.

Myers, S.C. and Majluf, N.S. (1984), "Corporate financing and investment decisions when firms have information that investors do not have", Journal of Financial Economics, Vol. 13 No. 2, pp. 187-221.

Payne, J. and W. Thomas (2010), 'The Torpedo Effect: Myth or Reality?', Journal of Accounting, Auditing and Finance (forthcoming).

Porter, M.E. (1980), Competitive Strategy: Techniques for Analyzing Industriesand Competitors, Free Press, New York, NY. 